\title{
Gabór B. Albert (Hungary) \\ History of Phases in Textbook Revisions at the 1928 Oslo Conference from the Hungarian Perspective
}

\begin{abstract}
Summary: This study is focused on phases of the textbook revision movement and textbook debates from the Oslo Conference organized by the International Committee of Historians in 1928. It is based on interviews by the contemporary Norwegian newspaper "Aftenposten" and on reports to the Hungarian Ministry of Education written by the Hungarian conference delegate, Sandor Domanovszky, one of the greatest Hungarian historians and authors of textbooks. Further, the author examines Kuno Klebelsberg's (leader of the Hungarian Ministry of Education between 1922 and 1931) attitudes to the textbook issue. After World War I the Hungarian textbook revision movement was examined in depth by the institutions of the League of Nations, and at events of the International Committee of Historical Science (Comité International des Sciences Historiques - CISH). The textbook revision movement aimed to filter out tendentious and distorted prejudices towards other nations in history textbooks.
\end{abstract}

Keywords: Oslo Conference 1928, textbook revision movement, textbook debates, International Committee of Historical Science, history textbooks

Резюме (Габор Б. Альберт: Исторические фазы ревизий учебников на конференции в Осло, в 1928 году, с венгерской точки зрения): Данное исследование концентрируется на фазах ревизии школьного учебника дебатах о школьном учебнике на конференции историков в Осло в 1928 году, организованной Международным комитетом историков. Оно основано на интервью норвежского журнала того времени «Афтенпостен», а также на отчетах Венгерскому Министерству образования, составленных венгерским участником конференции Сандором Домановски, одного из крупнейших венгерских историков и авторов учебников. Далее исследуется деятельность Куно Клебельсберга (венгерский министр образования с 1922 до 1931) по теме учебников. Ревизией венгерских учебников наряду с органами Народного Союза глубоко занимался Международный комитет исторической науки (Comité International des Sciences Historiques = CISH). Целью движения ревизии учебников являлось освобождение учебников истории от тенденциозных $и$ деформированных мнений и предосудительных мнений, касающихся других народов.

Ключевые слова: конференция историков 1928 года, движение ревизии учебников, дебаты по поводу учебников, Международный комитет исторической науки, учебники по истории

Zusammenfassung Zur Geschichte der Phasen der Lehrbuchrevision in der Oslo-Konferenz von 1928): Diese Studie konzentriert sich auf die Phasen der Lehrbuchrevision und auf die Lehrbuchdebatten der Historikerkonferenz in Oslo 1928, organisiert vom Internationalen Historikerkomitee. Sie basiert auf Interviews der zeitgenössischen norwegischen Zeitschrift "Aftenposten" sowie auf Berichten an das Ungarische Bildungsministerium, verfasst von dem ungarischen Konferenzdeligierten Sandor Domanovszky, einem der größten ungarischen Historiker und Lehrbuchautoren. Weiterhin werden die Haltungen von Kuno Klebelsberg (Ungarischer Kultusminister von 1922 bis 1931) zum Thema Lehrbücher untersucht. Mit der ungarischen Lehrbuchrevision beschäftigten sich tiefgehend neben den Organen des Volksbundes die Veranstaltungen des Internationalen Komitees für Geschichtswissenschaft (Comité International des Sciences Historiques = CISH). Das Ziel der Lehrbuchrevisionsbewegung war, die anderen Völker betreffenden tendenziösen und deformierten Äußerungen und Vorurteile aus den Geschichtsbüchern herauszufiltern.

Stichwörter: Historikerkonferenz 1928, Lehrbuchrevisionsbewegung, Lehrbuchdebatten, Internationales Komitee der Geschichtswissenschaft, Geschichtslehrbücher 


\section{The frame of research, its resource base and place in the taxonomy of sciences}

We can read in a book published in English in 1933 (School text-book revision and international understanding, 1933) that 20 transnational organisations paid attention to textbook revision after the Great War. The textbook-revision movement aimed to filter out tendentious and distorted prejudices towards other nations in history textbooks.

In Hungarian studies and books on the history of education the first one focuses on the history of the transnational textbook-revision movement between the two world wars. It is "The basics of textbook research" (2002) written by Ágnes Dárdai. In her book the author draws attention to the systematic historical processing of Hungarian aspects of the movement. Since then some different publications have appeared on this topic (such as Albert, 2008, Ujváry, 2014).

Besides the institutions of the League of Nations the events of the Comite International des Sciences Historiques (CISH) examined the Hungarian textbook revision in depth.

The history of congresses organised by CISH was summarized by its former chairman, the German historian Karl Dietrich Erdmann in German in 1987 (Erdmann, 1987), and his book was translated in English in 2005 (Erdmann, 2005). The historical summary of the Transnational Committee was subtitled Cleavages and Goodwill. The "Spirit of Oslo" provided detailed information about the Congress for Historians organised in the Norwegian capital city in 1928. The will of mutual understanding, the spirit of Oslo, was manifested by the chairman of the congress, Halvdan Koht. With scientific skills, language skills and good manners, Koht achieved change in the attitude of historians from the hostile states, especially in the attitude of the Soviet Marxist historians. At the beginning they were hostile and passive, but at the end of the conference their behaviour changed, a discussion started between them (Erdmann, 2005). Besides Erdmann's study the contemporary transnational bulletins, ${ }^{1}$ and the conference-interviews ${ }^{2}$ published in Aftenposten, the Norwegian newspaper also help us to understand the history of the Congress of Oslo. Halvdan Koht, the chairman of the conference, wrote his book in 1962, which contains his personal remembrances (Koht, 1962).

The atmosphere of the congress was determined not only by scientific questions but by Soviet Marxist historians' (like Pokrovskij's) presence there. Gioacchino Volpe, the Italian historian who joined the Italian fascism movement, also participated in the conference.

In my study, quoting interviews taken from Aftenposten and reports by Domanovszky, I focus on the debates on textbooks of the Conference for Historians in Oslo in 1928. Further, I examine the attitude of the Hungarian Ministry of Culture/Education towards the textbook issue based on Domanovszky's replies to reports.

Among the Hungarian sources, particularly, documents of the Domanovszky heritage can be regarded as relevant historical sources. The leader of the delegation, Sándor Domanovszky, reported continuously on the Oslo conference to the Hungarian Ministry of Culture. At the 1928 conference the prominent cultural historian represented not only the Ministry of Culture/Education but the Hungarian Academy of Sciences and Pázmány Péter University of Sciences as well. As Domanovszky had a good relationship with Klebelsberg, he held on to his mandate in the 1930s. Glatz writes that in the 1930s Domanovszky was the "most influential organizer" of the transnational committee of 
historians, whose name was mentioned in transnational bulletins and this way in the historical summary of the Transnational Committee too (Glatz, 1990: 227).

\section{The debate between Secretary General Michel Lheritier and Italian delegate Gioacchino Volpe}

The $16^{\text {th }}$ session of the Congress focused on the textbook issue. The sharpest contrast appeared between the CISH secretary general Michel Lheritier, one of the organizers of the conference, and the Italian historian Gioacchino Volpe. Lheritier was the one of the most important persons of the textbook-revision movement. In the 'Teaching History' session he drafted intentions so that teaching History in schools could serve peace. The Italian historian Gioacchino Volpe was named a strange element at the conference by Erdmann, and because he joined the fascist movement he was similar to the soviet Marxist historians (Erdmann, 2005: 134). In his report Volpe strongly criticized the secretary general of CISH: "Lheritier wanted to turn historical instruction into propaganda for internationalism and peace." (Erdmann, 2005: 134). Volpe strongly attacked Lheritier and debated the idealization of peace. He wrote: „The educators teach peace, to be sure, but certainly they teach war as well, if necessary..." (Erdmann, 2005: 134). Lheritier regretted that Volpe interpreted his lecture in a wrong way. Lheritier's opinion was that a historian only has to look for justice and present the facts of history in the most objective way. Lheritier believed that studying science and the entire world history objectively would unintentionally guide a student to a peace conviction. ${ }^{3}$ It was the first fight with political overtones between Lheritier and Volpe in Oslo. Their debate went on in Venice in 1929, and it extremely increased the Franco-Italian conflict, which was not free from political overtones. Volpe proposed dissolving CISH then, and Pietro Fedele, former Italian minister of education, criticized the organisation because it wanted to interfere in the domestic policy of countries. ${ }^{4}$

\section{Nicolae Jorga, Domanovszky Sándor and the textbook issue}

Aftenposten reported scientific and political issues as well. The Norwegian quality newspaper interviewed the Belgian Henri Pirenne, the Austrian Alfons Dopsch, the Soviet Rostovtzeff and Mihail Pokrovskij, and also the Romanian and Hungarian historians, Nicolae Iorga and Sándor Domanovszky.

The interview with the Hungarian professor counterbalanced the interview with the Romanian professor Iorga. Domanovszky emphasised the role of resource research, Klebelsberg's role, the status of the Hungarian publication of periodicals and the increased interest in history research. ${ }^{5}$

Although the question of textbook revisions was not mentioned in these interviews, to discuss the topic, it is important to introduce briefly the textbook-writing activities of two historians. All the more, the Hungarian Ministry of Culture thoroughly examined the textbooks of Romania. Domanovszky was a scholar-author who knew the Romanian textbooks on the market. He proved it in his detailed report on the Oslo Conference. Domanovszky also wrote textbooks. He wrote a book series for secondary schools at Klebelsberg's request. These textbooks were printed by Royal Hungarian University Press (Domanovszky, 1926, 1927, 1928, 1929, 1930, 1931). These books were scientifically demanding and had positivist thoroughness - proved by evaluation reports on them. ${ }^{6}$ The demand for these books decreased from 1928 (partly because of their complicated scientific language). ${ }^{7}$ After that Domanovszky became the most outstanding representative of the Hungarian textbook revision movement abroad. He studied transnational textbooks and curricula too. ${ }^{8} \mathrm{He}$ was well informed about Norwegian, Polish, German, and Italian textbooks. He knew the Romanian historian Nicolae Iorga's textbook-writing activity too. Nicolae Iorga wrote his first textbook in 1910. The Hungarian Ministry of Culture studied the Romanian historian's textbooks in depth. 
Iorga wrote the governmental authorities-aided textbook 'Istoria Romanilor'. Endre Barabás described the anti-Hungarian parts in his manuscript summary "Additions to the spirit of Romanian textbooks" in 1930. Nicolae Iorga's textbook "Istoria Romanilor" was considered as the basic source of historical textbook literature in Romania. The textbook was written for secondary schools. In his analysis Barabás quoted in detail from Iorga's textbook. The Romanian author's sentences, like King Sigismund's "Hungarians behaving like villains", or "the good-for-nothing Lewis the $2^{\text {nd }}$ who drowned in a swamp" prove his negative partiality against Hungarian history. ${ }^{9}$ Quotations from Iorga's textbook also can be read in Ferenc Olay's book from 1933.10

\section{A textbook criticism by a teacher from Érsekújvár and the response memorandum}

We know about a Hungarian-related episode of textbook revision at the Oslo conference. Domanovszky reported on it to Kuno Klebelsberg on $4^{\text {th }}$ October $1928 .{ }^{11}$ At the congress the two-volume book "Report on nationalism in history textbooks" edited by the Swedish advisor, Wilhelm Carlgreen (Carlgreen, 1928), was handed out. The two volumes were published by the Word Alliance for Promoting International Friendship through the Churches. This book didn't belong to the official conference publications. In this book, František Loubal, a teacher from Érsekújvár, strongly criticized Hungarian history textbooks. Loubal found that the Hungarian textbooks don't write enough about Slovakian history. For example, Comenius' cultural role was not emphasized in Hungarian textbooks. Loubal mentioned a Czech textbook writer, who had named the Germans and the Hungarians "murderers of our souls". It was easy to disprove Loubal's words, because he analysed withdrawn Hungarian textbooks. Domanovszky urged writing a response memorandum in several letters to Klebelsberg. The reponse memorandum disproving Loubal's accusations was disclosed at the CISH consultation in 1929. The memorandum Bemerkungen ${ }^{12}$ emphasized the strict evaluation system of the Hungarian textbook committee formed in 1925. Therefore Loubal might have known the official list of textbooks on the market. But for his analysis he didn't select an appropriate textbook. Wilhelm Carlgreen felt sorry about the fact that before publishing his book he hadn't checked the Slovakian teacher's writing with caution.

\section{Reactions of the Hungarian Ministry of Culture to the textbook revision work}

Domanovszky wrote about the debates on textbook revisions in detail. Domanovszky's letter of October $31^{\text {st }}, 1928^{13}$ at several points refers to his earlier letter of October4th 1928 . $^{14}$ In the earlier letter Domanovszky gives a detailed report about the events of the Oslo congress, including Luobal's study. Domanovszky urged the response to this study again in his proposal of October $31^{\text {st }}$. He also suggested sending this response to the Word Alliance for Promoting International Friendship through the Churches organisation. We are sure that Domanovszky realized the importance of the textbook-revision issue from the aspect of foreign cultural policy and foreign propaganda.

In the marginal notes of his October $31^{\text {st }}$ letter there were 3 surnames: Pechány, Madzsar and Horváth. Adolf Pechány was a representative of the Czechoslovakian textbook revision. Imre Madzsar had an active role in working out the curriculum of History for secondary schools. The surname Horváth surely refers to Jenő Horváth, was the executive director, later vice-chair of the Hungarian Society of Foreign Affairs between 1920 and 1933, and he represented the revisionist Hungarian foreign propaganda. We don't know who put down these three surnames and why. What is sure: all three people were experienced in the textbook trade. 
Klebelsberg wrote the following words about Domanovszky's letter of October 31'st, 1928: "I place a special stress on it." It proves two things. One the one hand: the letter was delivered to Klebelsberg. On the other hand: the Hungarian Ministry of Culture obviously was strongly interested in the issue of Hungarian textbook revisions.

\section{Summary and Conclusions}

In the history of the Hungarian textbook-revision movement the Oslo Conference of Historians is considered an important milestone.

In his reports, Sandor Domanovszky drew the attention of the Hungarian Ministry of Education to the fact that the textbook issue is an important part of cultural diplomacy. He pointed out the relevance of textbook revisions, and the fact that History teaching and textbook writing were strongly influenced by national aspects. It is proved by Volpe's and Lheritier's debate. In his reports on the Oslo Conference, Domanovszky wrote in detail about negative and prejudiced expressions against Hungarian history teaching and history textbooks by the neighbouring countries. He knew Jorga's, the textbook witer's, work. He urged writing a response memorandum to Loubal's study on Hungarian history teaching and history textbooks because it included numerous incorrect and distorted statements. At the same time, Domanovszky drew Kuno Klebelsberg's attention to the point that it is essential to delete false views on other nations from Hungarian textbooks as well.

New explorations of data related to textbook revisions of the Oslo congress justify the problem-based reinterpretation of history teaching and the history of textbooks between the two world wars.

Beside historians numerous educational and other organisations played a role in the textbook-revision movement too. We can think of one of the most important educational historians, Ernő Fináczy, who had an active part in the Hungarian textbook-revision movement too. But we don't know much about his work.

The Aftenposten interviews draw our attention to the interviewees' textbook-writing work. In my study I mentioned Iorga's textbook-writing activity, but it is worth studying the textbook authors in depth, like Vanag's work, who belonged to the outstanding Soviet historian Mihail Pokrovszkij's school of history. How were these authors sacrificed by Stalin's cult of personality? It requires research of cultural-contactology type to find if there were any contact networks of textbook writers between the Hungarian and the Soviet (Russian) authors. We have got little information about whether the reform pedagogy affected Hungarian textbook writing or not.

It is worth studying how Klebelsberg's research may be widened. Klebelsberg was determined to educate the elite who is experienced in foreign propaganda, speak foreign languages and is at home in Europe. Who was involved in the Hungarian textbook-revision movement besides Domanovszky, and what were the intentions? Could the Hungarian Ministry of Culture be successful? How were the achievements of the textbook-revision movement between the two world wars built into the textbook-revision movement reborn after the Second World War? Or do we need to apply the theory of abolishing the past completely and in this way forget the work between the two wars?

\section{References}

A Handbook for the improvement of textbooks and teaching materials. (1949). UNESCO, 30. 
Albert, B. G. (2008): The Hungarian textbook revision movement between the two world wars. In: Századok. 142 (1), pp. 63-78.

Bulletin, Section 14. Enseignement de l'Histoire. 144-146.

Dárdai, Á. (2002): The basics of textbook research. Budapest-Pécs: Dialog Campus Publisher. pp. 2631.

Domanovszky, S. (1926): The History of Hungary. For the 3rd class of Secondary Schools. Budapest: Royal Hungarian University Press.

Domanovszky, S. (1927): The History of Ancient Times till 180 AD. For the 4th class of Secondary Schools. Budapest: Royal Hungarian University Press.

Domanovszky, S. (1928): World history from the soldier emperors' period to the golden age of institutions in the middle ages. Budapest: Royal Hungarian University Press.

Domanovszky, S. (1929): World History from the decline of Medieval Institutions till the period of Enlightenment. For the $4^{\text {th }}$ class of Secondary School. Budapest: Royal Hungarian University Press.

Domanovszky, S. (1930): World History. From breaking out the French Revolution until now for the 7 th class of Secondary Schools. Budapest: Royal Hungarian University Press.

Domanovszky, S. (1931): Hungarian History. For the 8th class of Secondary Schools. Budapest: Royal Hungarian University Press.

Carlgreen, W. (Ed.) (1928): Report on nationalism in history textbooks. Prepared and compiled by the working committee of a special commission on education. Stockholm: A.-B. Magn. Bergvallas Förlag.

Erdmann, K. D. (1987): Die Ökumene der Historiker. Geschichte der Internationalen Historikerkongresse und des Comité International des Sciences Historiques. Göttingen: Vandenhoeck \& Ruprecht.

Erdmann, K. D. (1987): Toward a Global Community of Historians. The International Historical Congresses and the International Committee of Historical Sciences. 1898-2000. (Re-issued 2005 by Kocka, J., Mommsen, W.J., in collaboration with Blänsdorf, A.; translated from the German by Nothnagle, A.). New York-Oxford: Berghahn Books.

Glatz, F. (1990): A Habsburg Palatine in the Hungarian historiography (Sándor Domanovszky: József Palatine's documents of manuscripts edited in 1988). In: Historiography in Changing Era. Budapest: Gondolat, pp. 226-262.

Hungarian Academy of Sciences Manuscript Collection, (Further: MTAKK) Ms 4519/66. Domanovszky's letter to Klebelsberg (29 July, 1929) about the consultation in Venice.

Koht, H. (1962): The Origin and Beginning of the International Committee of Historical Science. Personal Remembrances. Lausanne.

MOL K 636-1932-1936-65-14. box no. 668 18. poz. Romanian textbooks. Barabás, 1930

MTAKK Ms 4519/61 Domanovszky's letter of 31 ${ }^{\text {st }}$ October, 1928

MTAKK Ms. 4519/56 Domanovszky's letter of $4^{\text {th }}$ October, 1928

MTAKK Ms 4532/38. Dr. Sándor Domanovszky: Difficulties in usability of Hungarian History textbook (for 3rd class of Secondary Schools)

MTAKK Ms 4532/1-47 Sándor Domanovszky's documents on publishing his history textbooks 19081942

MTAKK Ms 4519/65 Bemerkungen. Zu F. Loubals Kritik der magyarischen Lehrbücher, erschienen im I. Band des Raport on nationalism in history textbooks. Stokholm, 1928, pp.68-76.

Professor Pokrovsky uttaler sig til"Aftenposten" Aftenposten, 17. aug., 1928.

Professor Rostovtzeff om bolsjevikenes deltagelse i historiker-kongressen. Aftenposten, 15. aug., 1928.

Rumeniens representant på historikerkongressen. Nogen ord med professor N. Iorga fra Bukarest. Aftenposten, Oslo, tirsdag 14. august, 1928. 
Section 14. Enseignement de l'Histoire. in Bulletin of the International Commitee of Historical Sciences. VI. Congrés international des Sciences Historiques Oslo. 1928. Actes du Congrés. Le Comité. ORGANISATEUR DU CONGRĒS 1929, pp.141-150.

School Text-Book Revision and International Understanding (1933). Paris: International Institute of Intellectual Cooperation. 2nd. rev. Ed.

Ujváry, G. (2015): Debate on textbooks. Hungarian and German attempts to modify each other's textbooks during the Second World War. In: Bordás, S. \& Glavanovics, A. (Eds.): Possibilities of handling our historical traumas in psychological approach. KJF, Székesfehérvár, pp. 79-123.

Ungarsk historisk videnskap. En samtale med professor Domanovszky fra Budapest. Aftenposten, 18. august 1928, Nr. 417.

1 Section 14. Enseignement de l'Histoire. in Bulletin of the International Commitee of Historical Sciences. VI. Congrés international des Sciences Historiques Oslo. 1928. Actes du Congrés. Le Comité. ORGANISATEUR DU CONGRĒS 1929,pp. 141-150.

2 Professor Rostovtzeff om bolsjevikenes deltagelse i historiker-kongressen. Aftenposten, 15. aug. 1928. Professor Pokrovsky uttaler sig til"Aftenposten" Aftenposten, 17. aug. 1928. Rumeniens representant på historikerkongressen. Nogen ord med professor N. Iorga fra Bukarest. Aftenposten, Oslo, tirsdag 14. august 1928. Ungarsk historisk videnskap. En samtale med professor Domanovszky fra Budapest. Aftenposten 18. august 1928, Nr. 417.

3 Bulletin, Section 14. Enseignement de l'Histoire, pp.144-146.

4 Hungarian Academy of Sciences Manuscripts Ms (further: MTAKK Ms) 4519/66. Domanovszky's letter to Klebelsberg (29 July, 1929)

5 Ungarsk historisk videnskap. En samtale med professor Domanovszky fra Budapest. Aftenposten 18. august, 1928, Nr. 417.

6 E.g. MTAKK Ms 4532/38. Dr. Sándor Domanovszky: Difficulties in usability of Hungarian History textbook (for 3rd class of Secondary Schools).

$7 \quad$ MTAKK Ms 4532/1-47 Sándor Domanovszky's documents on publishing his history textbooks 1908-1942.

8 MTAKK Ms 4519/67 Domanovszky's letter to Klebelsberg (13 December 1929).

9 Hungarian Archives K (MOL K) 636-1932-1936-65-14. box no. 668 18. poz. Romanian textbooks. Barabás, 1930

10 Olay, F. (1934): What do the Romanians teach? Budapest: Hungarian National Alliance, pp. 27-28.

11 MTAKK Ms. 4519/56 Domanovszky's letter of $4^{\text {st }}$ October, 1928

12 MTAKK Ms 4519/65. Bemerkungen. Zu F. Loubal Kritik der magyarischen Lehrbücher, erschienen im I. Band des Raport on nationalism in history textbooks, Stokholm, 1928, pp. 68-76. 
13 MTAKK Ms 4519/61 Domanovszky's letter of 31 ${ }^{\text {st }}$ October, 1928.

14 MTAKK Ms. 4519/56 Domanovszky's letter of $4^{\text {th }}$ October, 1928.

\section{About the Author}

Dr. Gábor Albert: Historian of education, Kaposvar University, Hungary; contact: albert.gabor@ke.hu 